\title{
Seeing Local Wisdom as Form of Visual Art for Creating Place Identity in Kampung Pelangi, Semarang
}

\author{
${ }^{1}$ Bandung Institute of Technology, Bandung 40132, West Java, Indonesia \\ *Corresponding author.Email: ernest.irwandi@uph.edu \\ ${ }^{* *}$ Corresponding author. Email: setiawansabana@yahoo.com \\ ${ }^{* * *}$ Corresponding author.Email: twinrik@gmail.com
}

Ernest Irwandi ${ }^{1, *}$, Setiawan Sabana ${ }^{1, * *}$, Andryanto Rikrik Kusmara ${ }^{1, * * *}$

\begin{abstract}
Villages with mural decorations had spread across Java and become new tourist attractions, some of those villages are: Villages on the banks of Code River in Yogyakarta, Jodipan Village in Malang, Rainbow Village in Randusari Semarang and many more. Mural creations that emerge across many urban villages in Java island Indonesia was a clear example how art can create social impacts. Mural not only function as decoration but able to transform an area into a productive space. This paper discusses the process of community mural in transforming a place into creative spaces and encourage residents to explore their local potentials, thus create a place of identity. This research focused on Kampung Wonosari in Randusari Semarang or currently known as Kampung Pelangi (Rainbow Village). Despite many potentials that can be found in Kampung Pelangi, it was chosen as the location of this research based on several problems; first Kampung Pelangi has become new icon for Semarang City but seems discontinued with its traditional values, second how will Kampung Pelangi sustain as an attractive destination? The location of Kampung Pelangi is surrounded by historic sites and it has a unique local content that can be further explored. This study focused on cultural heritage, local wisdom and to understand sociocultural development of Kampung Pelangi amid the modernization of Semarang City. This study is a qualitative research using mixed methods with ethnographic and participatory approach.
\end{abstract}

Keywords: Visual Culture, Local Wisdom, Mural Art, Place Identity

\section{INTRODUCTION}

Writings or paintings on wall have been around for thousands of years and serve different functions in each era. Paintings on wall in Leang Petta Kere Maros South Sulawesi, was estimated to have been made 39.900 years ago [1]. Today, looking at cave painting in Petta Kere is to imagine the past but when it was made perhaps to mark an existence of a tribe or to educate generation about their surroundings.

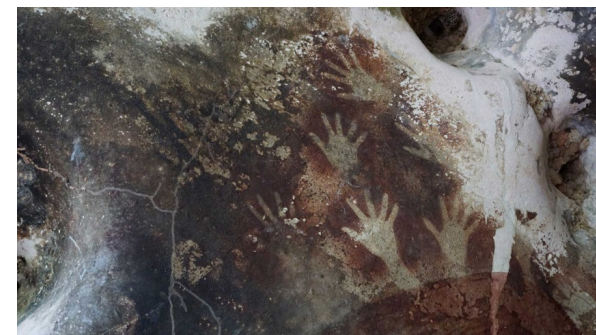

Figure 1 Mural Leang Petta Kere, Maros Sulawesi Selatan

Photo by: Mohamad Final Daeng

Source: interaktif.kompas.id/maros_cave
There are various definitions for paintings on wall such as: mural, graffiti or petroglyph. The etymology of the word mural comes from the Latin "murus" which means wall. Mural is an art work painted or applied directly to walls, ceilings, or the permanent surface or structure of a building [2]. Murals must be distinguished from graffiti, although both mural and graffiti use walls as medium. The etymology of the word graffiti comes from the Italian word "grafitto" which means scratch, carved, engraved or created by using stroke technique on one layer of pigment to reveal another layer underneath [3]. Petroglyph and graffiti share similar definition, petroglyph simply graffiti made by humans in prehistoric times [4]. Definition of graffiti has evolved both in technical term and in context. Main characteristic of graffiti is to use strokes or scribbles as visual elements, and generally aims to signify the existence of a person or group. 
Most murals and graffities are set in public, typically outdoors, created in vacant sites or urban free space. Today graffiti and murals in public spaces in urban areas are defined differently by city regulations, the fundamental difference between graffiti and murals lies in the ownership of the medium. In general, graffiti is writing or painting on walls of buildings without authorization or permission by property owner and often labelled as an act of vandalism, while murals require permission from property owner and what will be depicted by the mural, involves dialogue between the property owner and the artist.

The complexity of the mural follows the complexity of civilization. Today mural is an important visual communication tool often used to convey social, political messages or voice public opinion, or as a symbol of solidarity. According to Barnett, wall painting is a 'people's art', and claimed that mural painting is the most democratic art America has ever produced, because murals can be a catalyst, capable of initiating social or political change [5]. In South Africa, mural is used as tools for empowerment of communities; it is used as education media, help skills development, serve as a form of cultural expressions, create sense of place, and mark an establishment of a community identity [6].

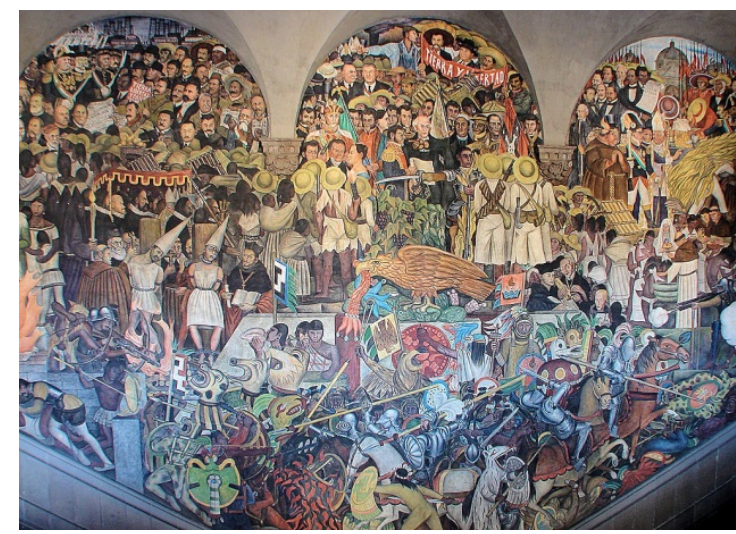

Figure 2 Diego Rivera Mural "The History of Mexico" National Palace, Mexico City

Source: www.wikiart.org

Mural can empower viewers to imagine the past or the future, altering our conception of time and memory, for example Diego Rivera's "Mexican History" mural in National Palace Mexico City appears as a historical document. In this mural, Diego Rivera paints a crowd of figures with superimposed techniques that give the impression of living figures from different eras, meeting and jostling in the same time and space. Each figure he painted represented roles in Mexican history which are rich with stories of saviour, heroes and cruel oppressors. Diego Rivera's mural is important to the national identity of Mexico because of its didactic influence in the context of history and social life. Through the figures in his mural work, Rivera introduces a new concept of nationalism which is an overview of the Mexican past, Rivera tries to motivate Mexicans and give sense of pride of their nation.
"Mexican History" mural is not just a spectacle but also a history lesson for Mexicans [7].

Mural and graffiti can also be used to mediate communal and personal expressions or visualize distinctive local identity. In urban areas murals and graffiti exist in various forms and context. In 1960-1970s murals and graffiti in America often seen as a form of resistance or part of Civil Rights movements, and these murals or graffiti became more visible on the exteriors of buildings, often in neglected neighbourhood [8]. Mural work can be a commercial medium or work by individual artist. There are also murals created by means of collaboration, which involve participation of communities, this movement referred to as 'community murals.' Community murals produced by the initiative of local communities rather by corporate, sometimes state or corporate offer some financial support but the themes of murals are selected by local people. It is a collective work rather than individual. In Chicago there was famous mural titled 'Wall of Respect' which was a significant community mural, created in 1967 and later destroyed in 1971. In 'Wall of Respect' mural, there are paintings of heroic recognizable African American: Muhammad Ali, Malcom X, John Coltrane and Nina Simone to inspire success stories of African American community [9]. During 1980s in London, New York or California, murals are art projects that transform streets into galleries. The terms 'Painting the Town' is a movement that turn the city as the canvas.

Entering millennium era, murals in the city tell various underlying social and cultural issues. Most of mural movement expresses environmental issues, cultural issues and concerns about neighbourhood and marginalization. Many citizens lived in cities and not aware of their future city development because most city is developed by decisions from the 'elite' and often followed by problems of gentrification. In many cities across the world there are many stories about shifting neighbourhood into development of new and expensive housing and business district. Since Industrial revolution, the expansion of cities has caused many social problems throughout the world with a variety of underlying factors. The problem of disparity in a city between modern buildings and slum areas has emerged in England at the beginning of the industrial revolution era in the 18th century. Hundreds of years on, the problems of disparity still faced by many countries, slum areas have become uninhabitable. 


\section{MURALS IN URBAN VILLAGES OF JAVA}

In the city of Yogyakarta, art movements in public spaces such as mural, graffiti and installation art, are part of street art culture, and the art movement continued by artists across generations. In 2002 one of art community in Yogyakarta, Apotik Komik used murals to beautify the city from the 'ugliness' of graffiti. Viewed in this perspective, mural appear as saviour from the littering walls of graffiti in public spaces but this notion of 'mural vs graffiti' often start a never-ending debate. Nevertheless, mural project carried out by the Apotik Komik has inspired many communities and its domino effect can be seen today in Yogyakarta [10].

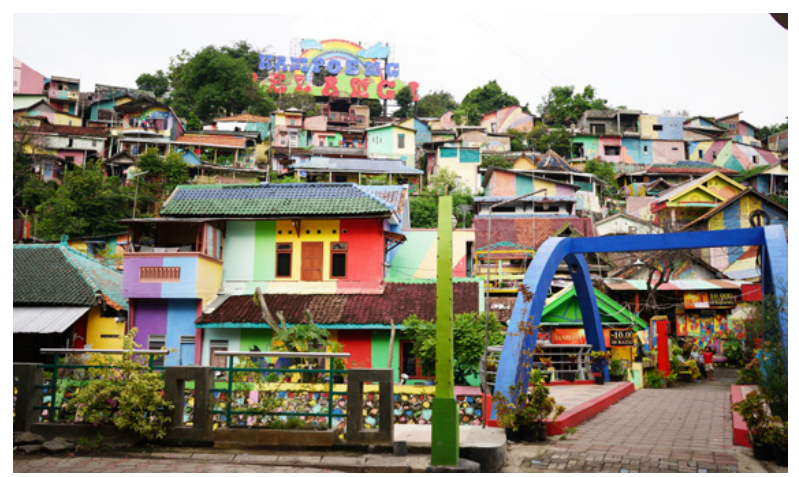

Figure 3 Kampung Pelangi Entrance

For almost a decade, decorating urban villages with mural have become a movement across Java. Several urban villages have evolved to be tourist destinations and attract many visitors. The villages decorated with murals on the island of Java have a similar character; most of the villages are located in the middle of the city or known as 'kampung kota' or urban villages. The existence of urban villages in cities across Java Island can be traced from the Indonesian post-independence era when Indonesia entered early stage of city development. Since 1980 s most of the regions in Java have experienced regional expansion as a result of expanding economic activities. In the past, most settlements were surrounded with rice fields and forest, gradually developing into a city. The villages which has long existed, is now surrounded by modern buildings. In contrast with modern housing and buildings, several urban villages have minimal access to public facilities such as: clean water, security or waste management and residents have to strive for solution by themselves.

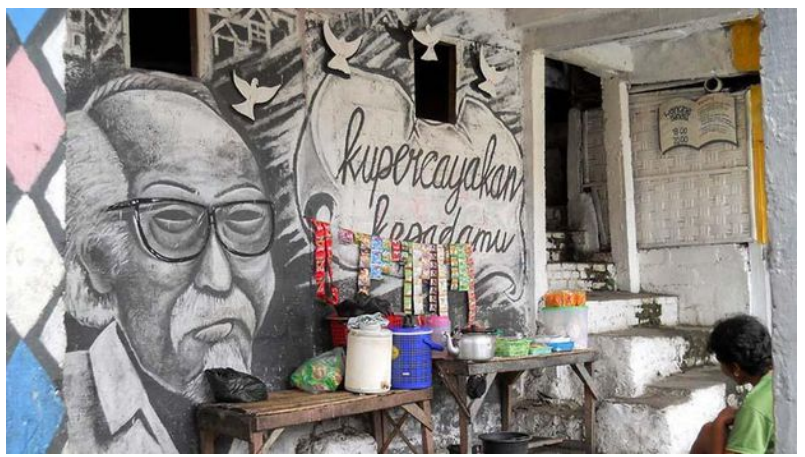

Figure 4 Mural of Romo Mangun

Source: Shabara Wicaksono, Detik Travel

The visitor's interest does not only stop at the colours visible outside the village but on the visual uniqueness in each village. The Kali Code village in Yogyakarta City is known as the story of Romo Mangun, architect that helped build the Kali Code Village, his services is still remembered and the figure of Romo Mangun is portrayed on the mural in Kali Code Village. In Jodipan Village, Malang City is known for its three-dimensional thematic paintings created by local art community. Kampung Bulak, Kenjeran in Surabaya is known for fishermen village. Cibunut village in Bandung City is known for its thematic murals and educational themes.

\section{LITERATURE REVIEW}

Before representing identity and how a community mural project will be developed, we need to understand the functional aspects of local myth, local values in relevance to the community. In Levi-Strauss structuralism myth is a fairy tale. A fairy tale is a story from human imagination, and the elements of imagination come from interactions in human life. A fairy tale is one way for humans to express their thoughts. A story in history can be considered as a series of events that occurred in the past or considered to be a fairy tale by other communities. Myth does not mean a sacred story that will always glorified by all, because for others the same story can be considered mediocre. For Levi Strauss, myth and language have something in common.

First, language is a medium or means of communication, a vehicle for delivering messages between individuals or groups, as well as myths. The messages in myths are understood through language and their meanings are arbitrary, so until now humans are still searching for and always trying to explore the messages that are considered to be behind various myths in the world. 
Second, similar to Saussure's view of language especially about the aspects of "langue" and "parole", Levi Strauss sees myths also having that aspect. Myth, as a language, consists of "langue" and "parole," both synchronous, ahistorical and diachronic structures related in chronological time [11]. The concept of parole to view myths explained by Levi Strauss, was further developed by Roland Barthes. According to Barthes any material can be seen as text and in practice it can be in the form of verbal, oral or written text is interpreted arbitrarily by the reader. Roland Barthes sees the interaction between text and personal experience within a culture. Barthes explained that within a culture there is a convention of meaning about the things that are experienced. The use of connotation in a culture is formed by the power of the majority, gives a certain connotation meaning to a thing, so that it will gradually become an inherent myth in a culture. So, myth is a development of connotation and connotation that settled in a community will manifest into a myth [12].

The practice of community mural is the process of attaining sense of identity, sense of belongingness and values. The result of community mural is not the appearances of the mural itself but the retaining intangible value [13].

\section{FINDINGS AND DISCUSSIONS}

This research focused on Kampung Wonosari in Randusari Semarang or currently known as Kampung Pelangi (Rainbow Village). It was chosen as the location of this research based on several factors; (1) Kampung Pelangi has become new icon for Semarang City but seems discontinued with its traditional values, (2) the colourful Kampung Pelangi has invited many visitors since it was inaugurated in 2017 but when the colours fade, will Kampung Pelangi managed to sustain and continue its creative development? Kampung Pelangi has unique local contents: Kampung Pelangi is surrounded by historic sites and its location was once part of Semarang historic narrative, there are also interesting urban legends or local myth that can be further studied. These are collections of local contents that interlocked within a narrative which shaped identity for the community.

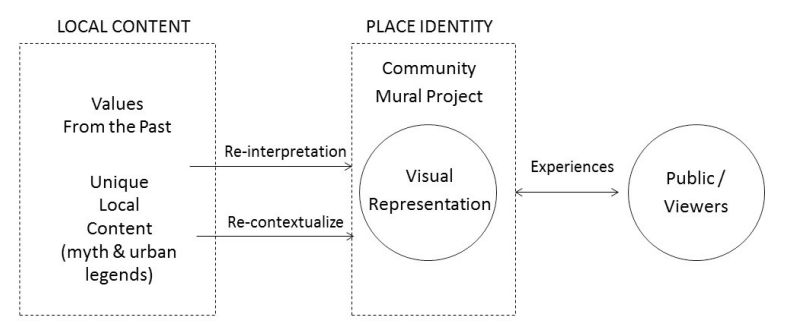

Figure 5 Visual Representation Process

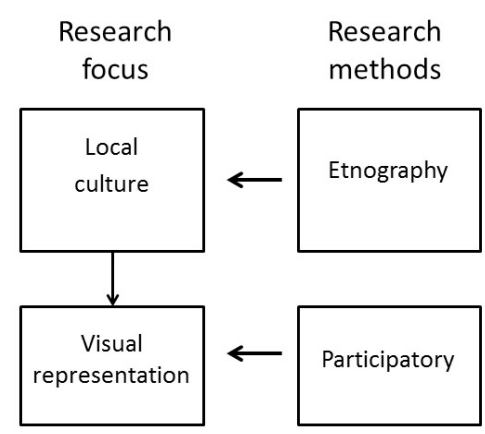

Figure 6 Research Approach

This research is to explore and study local culture in the urban villages in Java, especially in urban villages that are decorated with murals. This research is an in-depth study case focused in Kampung Pelangi, conducted with combination of interviews, participant observation and focused group discussions. This is qualitative research using a mixed approach with ethnographic approach to understand local culture, local wisdom and narratives based on historical texts, and a semiotic structural approach to expressing the values and symbolic meanings contained in myths.

Participatory approach will be used to analyse various creative collaborative models required in designing community mural projects, which involve participation of communities to narrate communal memories and local values.

\section{CONCLUSION}

This research is still at early stage, early findings in several villages decorated with mural in Java, proves what Barnett had mentioned that "murals function as a new way of being together" [14]. After conducting in depth interview with village seniors and local community in Kampung Pelangi Semarang in early 2019, there are findings that many local potentials still not yet represented. The colourful village has united villagers but have not, or still at early stage what Barnet said that "mural is able to help unify collective identities amongst the community members". In this early stage of research there is one assumption; the success of shaping identity through community mural projects is driven by key factors: creative process, local wisdom that is inherent within local myth and level of participation of communities, but this statement must be proven with further research findings at later stage of this research. 


\section{REFERENCES}

[1] Aubert, Maxime, et al. "Pleistocene cave art from Sulawesi, Indonesia." Nature 514.7521 (2014): 223. DOI: https://doi.org/10.1038/nature 13422

[2] Willsdon, Clare AP. Mural Painting in Britain 1840-1940: Image and Meaning. Vol. 22. Oxford University Press, USA, 2000. p. 394.

[3] Ancelet, Jeanine. "The history of graffiti." University of Central London. Retrieved April 20 (2006).

[4] Morris, Ronald WB. The Prehistoric Rock Art of Galloway \& the Isle of Man. Blandford Press, 1979.

[5] Barnett, Alan W. Community murals: The people's art. Associated Univ Pr, 1984.

[6] Marschall, Sabine. Community mural art in South Africa. Unisa Press, 2002.

[7] Cockcroft, Eva Sperling, John Pitman Weber, and James D. Cockcroft. Toward a people's art: The contemporary mural movement. University of New Mexico Press, 1998.

[8] Marschall, Sabine. Community mural art in South Africa. Unisa Press, 2002.

[9] Harris, Michael D. "Urban totems: The communal spirit of Black murals." Walls of heritage, walls of pride: African American murals (2000). p. 24.

[10] Barry, Syamsul. Jalan seni jalanan Yogyakarta. Studium, 2008.

[11] Lévi-Strauss, Claude, and Monique Layton. Structural anthropology. Chicago: University of Chicago Press, 1984.

[12] Barthes, Roland. "Elements of Semiology." New York: Hill \& Wang (1973).

[13] Tunnacliffe, Claire Malaika. "The Power of Urban Street Art in Re-naturing Urban Imaginations and Experiences." Development Planning Unit no. 182, 2016.

[14] Barnett, Alan W. Community murals: The people's art. Associated Univ Pr, 1984. 